\title{
A View of Titian's Mary Magdalene Ilene Moskin
}

She would hang herself

with her snarling hair,

yet her breast remains brilliant,

its nipple, a rakish crown, a spire.

I watch this Mary Magdalane

who kissed the young boy Jesus

and shadowed him to the well.

Lifted from his skull-

that plundered box on the table-

the gold that was his halo

winks now at her lips, her sleeve.

Kisses-even mourning,

Mary's mouth is brimming with them.

She cannot spit them out

like cherry stones.

The chilly god

crops out along her body.

She can't conceal the stolen gold. 